\title{
Cardiorespiratory and electrocardiographic effects of methadone or morphine in the perioperative period in anesthetized dogs with continuous rate infusion of propofol and submitted to ovariohysterectomy
}

\section{Efeitos cardiorrespiratórios e eletrocardiográficos da metadona ou morfina no período perioperatório em cães anestesiados com infusão contínua de propofol e submetidos a ovário-histerectomia}

\author{
Priscila Pavini Cintra ${ }^{1 *}$; Celina Tie Nishimori Duque ${ }^{2}$; Mariana Póvoa Silveira ${ }^{3}$; \\ Maria Augusta Adami Pereira dos Santos"; Mariana Miranda Vaz da Silva ${ }^{5}$; \\ Leandro Zuccolotto Crivellenti ${ }^{6}$; Ewaldo de Mattos Junior6
}

\begin{abstract}
The aims of this study were compare the electrocardiogram (ECG) and cardiopulmonary effects of methadone or morphine, both injected intravenously (IV) in dogs anesthetized with continuous infusion of propofol. Sixteen healthy female mongrel dogs were used in this study for elective ovariohysterectomy. The animals were allocated in random order into two groups assigned GME (methadone $0.3 \mathrm{mg} \mathrm{kg}^{-1}$, IV) or GMO (morphine $0.3 \mathrm{mg} \mathrm{kg}^{-1}, \mathrm{IV}$ ). Parameters were evaluated: heart rate (HR), P-wave amplitude (Ps and PmV), interval between Ps and R waves (PR), QRS duration (QRS), R-wave amplitude (R), duration the interval between the $\mathrm{Q}$ and $\mathrm{T}$ waves $(\mathrm{QT})$, systolic blood pressure (SBP), rectal temperature $(\mathrm{RT})$, respiratory rate $(\mathrm{RR})$, end tidal of carbon dioxide $\left(\mathrm{ETCO}_{2}\right)$ and periferic oxyhemoglobin saturation $\left(\mathrm{SpO}_{2}\right)$. Postoperative analgesia was assessed by mechanical nociceptive stimulus based on the scale proposed by Firth and Haldane (1999) and rescue analgesia based on the visual analogue scale. HR was lower in GME in relation to GMO. The P, PmV, PR, QRS, R and QT values remained within their normality tracks, showing no clinical importance. Apnea and $\mathrm{ETCO}_{2}$ increased in both groups. There was no difference between groups of the analgesic effects. It can be concluded that methadone and morphine promote similar cardiovascular effects after IV injection during surgery in dogs anesthetized with propofol by continuous rate infusion, however, when methadone used, assisted ventilation is required. In addition, both drugs promote postoperative analgesia until six hours.
\end{abstract}

Key words: Analgesia. Anesthesia. Canine. Pain.

${ }^{1}$ Discente do curso de doutorado do programa de Pós-Graduação em Ciências, Universidade de Franca, UNIFRAN, Franca, SP, Brasil. E-mail: ppcintra@yahoo.com.br

${ }^{2}$ Prof $^{a}$ Dra $^{\mathrm{a}}$, Pontifícia Universidade Católica do Paraná. PUC-PR, Escola de Ciências Agrárias e Medicina Veterinária, ECAMV, São José dos Pinhais, PR, Brasil. E-mail: celinatie@yahoo.com.br

${ }^{3}$ Prof ${ }^{a}$ M.e, Universidade Presidente Antônio Carlos, UNIPAC, Uberlândia, MG, Brasil. E-mail: marianaps@gmail.com

${ }^{4}$ Discente do curso de mestrado do programa de pós-graduação em Ciência Animal, Universidade de Franca, UNIFRAN, Franca, SP, Brasil.E-mail: guta.adami@gmail.com

${ }^{5}$ Médica Veterinária Autônoma, São Paulo, SP, Brasil. E-mail: mmarivet@gmail.com

${ }^{6}$ Profs. Drs., Universidade de Franca, UNIFRAN, Franca, SP, Brasil. E-mail: crivellenti_lz@yahoo.com.br; ewaldomattos@ hotmail.com

* Author for correspondence 


\section{Resumo}

O presente estudo teve como objetivo comparar as alterações no eletrocardiograma (ECG) e nos parâmetros cardiorrespiratórios da metadona ou morfina administrada pela via intravenosa (I.V.) em cães anestesiados com infusão intravenosa contínua de propofol. Foram utilizados 16 cadelas, sem raça definida submetidos ao procedimento de ovário-histerectomia. Os animais foram distribuídos aleatoriamente em dois grupos, designados como GME (metadona $0,3 \mathrm{mg} \mathrm{kg}^{-1}$, I.V.) ou GMO (morfina $0,3 \mathrm{mg} \mathrm{kg}^{-1}$, I.V.). Os parâmetros avaliados foram frequência cardíaca (FC), tempo e amplitude da onda P (Ps e PmV), intervalo entre as ondas P e R (PR), duração do complexo QRS (QRS), amplitude da onda $\mathrm{R}(\mathrm{R})$, duração do intervalo entre as ondas $\mathrm{Q}$ e $\mathrm{T}(\mathrm{QT})$, pressão arterial sistólica (PAS), temperatura retal (TR), frequência respiratória $(f)$, tensão de dióxido de carbono no final da expiração $\left(\mathrm{ETCO}_{2}\right)$ e saturação de oxigênio na hemoglobina $\left(\mathrm{SpO}_{2}\right)$. A analgesia pós-operatória foi verificada seguindo a proposta de Firth e Haldane (1999) e o regaste analgésico baseado na escala análoga visual. A FC foi menor no GME comparativamente ao GMO. Os valores de Ps, PmV, PR, QRS, R e QT mantiveram-se dentro da normalidade em ambos os grupos e sem significado clínico. Apneia e incremento da $\mathrm{ETCO}_{2}$ em ambos os grupos. Não houve diferença nos efeitos analgésicos entre os grupos. Podemos concluir que a metadona e a morfina promovem efeitos cardiovasculares similares quando administradas I.V. durante o procedimento cirúrgico em cães anestesiados com propofol via infusão continua intravenosa, no entanto, quando a metadona é empregada, ventilação assistida é necessária. Além disso, os dois opioides promoveram analgesia por $6 \mathrm{~h} 00$ no pós-operatório.

Palavras-chave: Analgesia. Anestesia. Canino. Dor.

\section{Introduction}

Opioid are widely used for pain management in the perioperative period, especially in invasive procedures (LERCHE; MUIR, 2008). Their mechanism of action involves binding to specific receptors located primarily in the spinal cord. Among these drugs, morphine and methadone stand out because of their potent analgesic effect (CARROLL, 2008).

While many opioid drugs have been synthesized in recent years, morphine is still widely used in pain control because of its high affinity for $\mu$ receptors (THURMON et al., 1996). Among their main adverse effects, respiratory depression with reduction in minute volume (JAFFE; MARTIN, 1991), increased partial pressure of carbon dioxide, and acidosis (THURMON et al., 1996) stand out, as well as cardiovascular changes, hypotension, premature ventricular contractions, and bradycardia (GUEDES et al., 2006; MONTEIRO et al., 2009).

Methadone is a $\mu$-opioid agonist that also has affinity for N-methyl-D-aspartate receptors (LAMONT; MATHEWS, 2007), showing a similar analgesic efficacy when compared with morphine. At doses varying from $0.5 \mathrm{mg} \mathrm{kg}^{-1}$ to $1 \mathrm{mg} \mathrm{kg}^{-1}$ the period of analgesia is 6 hours (INGVASTLARSSON et al., 2010), and at doses up to $0.3 \mathrm{mg}$ $\mathrm{kg}^{-1}$, cardiorespiratory effects are mild (PEREIRA et al., 2013).

Although morphine and methadone are widely used, comparative studies on their effects in perioperative analgesia are scarce. Therefore, this comparative study was conducted to verify the electrocardiographic and cardiovascular effects of these two opioids, administered intravenously, in dogs anesthetized with an intravenous continuous rate infusion of propofol.

\section{Materials and Methods}

This research was conducted under the approval and supervision of the Institutional Animal Ethics Committee at the University of Franca (protocol number 012/08A). All of the steps carefully followed the standards determined by the National Council of Animal Experimentation Control. 


\section{Animals}

Sixteen adult female mongrel dogs, healthy, with an average weight of $12 \pm 6.5 \mathrm{~kg}$, mean age of 5.4 \pm 2.4 years, and sent to the Veterinary Hospital for elective ovariohysterectomy, were used. Before the study, all owners were informed of the inclusion of their animals in the research and signed the informed consent form. A general clinical evaluation and laboratory tests, including a complete blood count and serum biochemical profile (urea, creatinine, alkaline phosphatase, alanine aminotransferase) and electrocardiogram were performed. Before the study, the animals were subjected to solid fasting for $12 \mathrm{hr}$ and water for $2 \mathrm{hr}$.

\section{Experimental design}

The selected animals were randomly assigned to two groups, methadone ( $\mathrm{GME}-\mathrm{n}=8)$ and morphine $(\mathrm{GMO}-\mathrm{n}=8)$, and received a dose of $0.05 \mathrm{mg}$ $\mathrm{kg}^{-1}$ acepromazine as pre-anesthetic medication that was administered intramuscularly. After $15 \mathrm{~min}$, a percutaneous IV access catheter was introduced (22 $\mathrm{G})$, and Ringer's Lactate solution was administered at the rate of $10 \mathrm{~mL} \mathrm{~kg}^{-1} \mathrm{~h}^{-1}$, throughout the procedure. The animals were then anesthetized with propofol at a dose of $5 \mathrm{mg} \mathrm{kg}^{-1}$, injected IV. Once adequate mandibular relaxation occurred, they were intubated with an endotracheal tube of suitable diameter, which was connected to the anesthesia circle breathing system, through which they received $100 \%$ oxygen at a rate of $1 \mathrm{~L} \mathrm{~min}^{-1}$ throughout the procedure. Immediately, continuous IV continuous rate infusion of propofol was initiated with infusion pump (Samtronic infusion pump, mod. 670T, São Paulo, SP, Brazil) at a dose of $0.9 \mathrm{mg} \mathrm{kg}^{-1} \mathrm{~min}^{-1}$.

After an anesthetic stabilization period of $30 \mathrm{~min}$, the GME and GMO groups received methadone or morphine, at a dose of $0.3 \mathrm{mg} \mathrm{kg}^{-1} \mathrm{IV}$ diluted in a $0.9 \%$ sodium chloride solution, for a final volume of $3 \mathrm{~mL}$, which was administered continuously for $5 \mathrm{~min}$. Immediately after administration of the drugs, the surgical procedure was started. The procedure was performed in all animals by the same professional.

Animals and protocols were chosen at random, and the professionals were blinded to the drug being administered. The room was kept at a temperature ranging from $22^{\circ} \mathrm{C}$ to $24^{\circ} \mathrm{C}$ throughout the procedure.

The parameters were assessed twice: intraoperatively and postoperatively. Intraoperative data were collected at the following time points: T0 or baseline (prior to the application of acepromazine); $15 \mathrm{~min}$ after the application of acepromazine; $\mathrm{T}_{\text {ind }}$ (immediately after induction); and T5, T10, T15, T20, T30, T40, T50, and T60 min after the administration of opioids. In the immediate postoperative period, when the animals had regained consciousness, the cardiovascular variables (non-invasive blood pressure and heart rate $[\mathrm{HR}]$ ), respiratory rate, rectal temperature, and analgesia scores were assessed at T120, T180, T240, T300, and T360 min.

\section{Parameters assessed}

The HR (bpm) was obtained through computerized electrocardiography (TEB, mod ECGPC software version 1.10, São Paulo, SP, Brazil), with electrodes placed on the limbs of the animals while respecting the derivation, D2, calculated from the interval between two $\mathrm{R}$ waves. Similarly, the heart rhythm was assessed, measuring the duration (Ps) and amplitude (PmV) values of the $\mathrm{P}$ wave, interval between $\mathrm{P}$ and $\mathrm{R}$ waves (PR, ms), duration of the QRS complex (QRS, ms), R-wave amplitude $(\mathrm{R}, \mathrm{mV})$, time interval between the $\mathrm{Q}$ and $\mathrm{T}$ waves (QT, ms), and interval between two $\mathrm{R}$ waves (RR, ms). The systolic blood pressure (SBP, mmHg) in the palmar digital artery of each animal was measured by an indirect method using ultrasonic Doppler and a calibrated manometer, with a cuff corresponding to $40 \%$ of the circumference of the carpal region, obtained by the mean of three consecutive measurements at each point, and the rectal temperature $\left({ }^{\circ} \mathrm{C}\right)$ using a digital thermometer. 
The respiratory rate $[f,(\mathrm{rpm})]$ and end tidal of carbon dioxide $\left(\mathrm{ETCO}_{2}-\mathrm{mmHg}\right)$ were obtained using an oxi-capnograph (DIXTAL mod DX 7100, Manaus, AM, Brazil), in which the flow sensor is coupled between the "Y" connection of the valve circuit and the endotracheal tube. The peripheral oxygen saturation $(\mathrm{SpO} 2, \%)$ was evaluated by the infrared sensor of the oxi-capnograph positioned in a glabrous and depigmented skin region.

Assessment of the immediate postoperative analgesia was performed by palpation of the surgical wound based on the scale proposed by Firth and Haldane (1999) as follows: $0=$ absence of analgesia, response to palpation with obvious signs of discomfort (attempts to move and/or vocalize); $1=$ moderate analgesia (no response to palpation, $20 \%$ increase in $f$ and HR compared with the value recorded immediately before the application of the stimulus); 2 = good analgesia (no response to palpation, $10 \%$ increase in $f$ and HR compared with the value recorded immediately before the application of the stimulus); and $3=$ complete analgesia (no response to palpation, no increase in $f$ and HR). In addition to the assessment of analgesia, we used a visual analog scale (VAS) in which zero represents no pain and 10 represents the worst imaginable pain, as previously described by Nolan and Reid (1993). When the animals had a VAS score above four, they were treated with morphine $(0.1$ $\left.\mathrm{mg} \mathrm{kg}^{-1}\right)$, administered intramuscularly as rescue medication.

\section{Statistical analysis}

Data are presented as means \pm standard deviations. Statistical analysis was performed using the software Jandel SigmaStat (SigmaStat for Windows, version 3.0.1. Systat Software Inc, Richmond, CA, USA). The Kolmogorov-Smirnov normality test was used to verify the distribution of the data. One-way analysis of variance (ANOVA) was used, followed by the Student-Newman-Keuls test to analyze variations between the groups.
For non-parametric data, the Kruskal-Wallis test, followed by the Student-Newman-Keuls test, were performed. To detect differences between time points and within each group, one-way ANOVA was used for repeated measurements, followed by the Student-Newman-Keuls test. The established significance level was $5 \%$.

\section{Results and Discussion}

The values of ECG analysis are presented in Table 1. There was no difference between groups in the mean values of the Ps variable, and a nonsignificant increase from T0 to T10 was observed in the GMO group. Although this result had no statistical or clinical significance, it may imply a slight delay of atrial electrical conduction, because there was an increase in the mean values of $\mathrm{P}$ wave duration after administration of the drugs in both groups. This variation may be related to hypothermia, although Nishimori (2006), who analyzed the electrocardiographic tracing of anesthetized dogs with different propofol infusion rates, did not observe a difference in the duration of the P wave. However, Nunes et al. (2004) and Santos et al. (2004) stated that one of the factors that kept this parameter constant in their studies was controlling body temperature and keeping it close to physiological values during the experimental period, thus avoiding any interference with the cardiac electrical dynamics. Regarding the PmV, there was no difference between the groups or the evaluation time points. Moreover, the values described remained within the normal range for the species (up to $0.4 \mathrm{mV}$ ), as reported by Goodwin (2002).

With regard to the PR interval, the average values of the GMO group were lower than those of the GME group at T0, 15 min after MPA, and T60. According to Goodwin (2002), PR interval prolongation above $130 \mathrm{~ms}$ indicates first-degree atrioventricular block; however, this phenomenon was not observed here because all values remained 
within the normal range for the species (60-130 ms). Similarly, Conceição (2006) found no change in this parameter by using propofol $\left(0.4 \mathrm{mg} \mathrm{kg}^{-1}\right.$ $\mathrm{min}^{-1}$ ) combined with fentanyl or sufentanil.

There was no significant difference for the duration of the QRS complex during the evaluation time; however, the mean values at T50 were higher for the GME group when compared with the GMO group. Thus, it can be stated that there was a slight prolongation of the time of ventricular electrical conductivity, but without clinical significance. The same result was obtained by Conceição (2006) and attributed to changes in body temperature, as according to Mattu et al.(2002), electrocardiographic manifestations of hypothermia include increased intervals of PR, QT, and QRS complex.

There was a reduction in $\mathrm{R}$-wave amplitude in animals treated with methadone at T10, T30, and T60. It could be hypothesized that this reduction was due to the change in impedance of the heart muscle, reflecting a possible increase in the electrical resistance in the ventricular muscle (SANTOS et al., 2000, 2001). Despite these changes having occurred, all R-wave amplitude values also remained within the normal range, with a maximum of $2.5 \mathrm{mV}$ for small breeds and a maximum of $3 \mathrm{mV}$ for large breeds (TILLEY; BURTNICK, 1999).

In the GMO group, all QT interval times were higher than the baseline, while in the GME group this was observed at T10, T15, and T20. Between the groups, it was only 15 min after the application of MPA that the QT interval was greater in GME compared with GMO. Therefore, the changes that occurred in both groups were probably caused by the administration of opioids, verifying that the parasympathetic action of these drugs culminates in the manifestation of negative chronotropism (VALADÃO et al., 2002).

No changes were observed in the analysis of the RR interval. The measurement of this variable is the period between ventricular contractions, hence it can be used to calculate the ventricular rate
(STEPHENSON, 1993), and represents the changes in HR that are inversely proportional to it (TILLEY, 1992). It has been observed that the RR interval follows variations in HR, with an increase in the mean interval as the HR decreases.

The HR values in the GME group were significantly lower than in GMO, at 15 min after MPA, at T10, and at T15 (Table 2). Binding to peripheral alpha1-adrenergic receptors may cause phenothiazine to induce peripheral vasodilatation, and consequently tachycardia (FANTONI; CORTOPASSI, 2002). This was reported in dogs treated with acepromazine and anesthetized with isoflurane (MONTEIRO et al., 2007; GRASSO et al., 2015) and would corroborate the data in this study, although only the GMO group showed significant changes.

It is known that methadone and morphine act on the $\mu$ agonist receptor, which promotes vagal stimulation in the spinal cord, increasing the vagal tone (STANLEY et al., 1980). However, methadone also has affinity for N-methyl-D-aspartate (NMDA) and alpha- 2 adrenergic receptors, the latter having cardiopulmonary properties including a reduction in $\mathrm{HR}$, which justifies the values found when compared to morphine (FANTONI; CORTOPASSI, 2002). Maiante et al. (2008) reported a cardiodepressant effect of methadone when comparing the cardiorespiratory effects of morphine in conscious dogs, by observing HR reductions of $28 \%$ and $48 \%$ from baseline values at doses of $0.5 \mathrm{mg} \mathrm{kg}^{-1}$ and $1 \mathrm{mg}$ $\mathrm{kg}^{-1}$ of methadone, respectively. Pereira et al. (2013) also observed bradycardia after the application of $0.3 \mathrm{mg} \mathrm{kg}^{-1} \mathrm{IV}$ methadone, as well as atrioventricular block in dogs undergoing ovariohysterectomy. In contrast, we did not observe bradycardia or cardiac arrhythmias, which may have been due to the antiarrhythmogenic effect of acepromazine (GRASSO et al., 2015).

With regard to $f$ all animals presented apnea (T5T60) in the GME group and a significant reduction in GMO at the time points T5 and T10. Significant 
difference were observed between groups in times T5-T60 (Table 2). In dogs, transient apnea is common after anesthetic induction with propofol (MURISON, 2001) and, similarly, $f$ may be reduced to $70 \%$, using continuous IV infusion at a dose of $0.8 \mathrm{mg} \mathrm{kg}^{-1} \mathrm{~min}^{-1}$ (FERRO et al., 2005). In conscious dogs, Maiante et al. (2008) did not observe severe respiratory depression after the application of IV morphine or methadone $\left(0.5 \mathrm{mg} \mathrm{kg}^{-1}\right)$. However, this effect becomes important when these agents are administered in combination with other depressant drugs of the respiratory system (CARDOSO et al., 2014), especially general anesthetics (WAGNER, 2002). Based on our literature review, the findings of this study that point to the occurrence of apnea with these associations, have not been reported previously, although it is clear that methadone can promote severe respiratory depression in association with propofol.

In this study, the $\mathrm{ETCO}_{2}$ values were higher in both groups after induction of anesthesia compared to T0 (Table 2). Cortopassi et al. (2000) found an increase in $\mathrm{PaCO}_{2}$ due to alfentanil administration that remained higher after the application of propofol. Therefore, it can be presumed that the increase in $\mathrm{ETCO}_{2}$ in this study may have been caused by the association of opioid drugs with the depressant effect of propofol on respiratory function. $\mathrm{SpO}_{2}$ values remained within the physiological values for the species, and were statistically inferior only 15 min after MPA in the GMO group.

Reductions in the amount of plasma hemoglobin can be observed after administration of phenothiazine in splenic vasodilation (FANTONI; CORTOPASSI, 2002). Another important factor that should be taken into consideration is before orotracheal intubation, the animals were breathing ambient air oxygen, while the rest of the time, they received $100 \%$ oxygen, thus justifying the $\mathrm{SpO}_{2}$ difference between the evaluation time points. Constant values of saturation of oxyhemoglobin during the entire experimental period were described by Pires et al. (2000), who attributed this observation to the use of adequate oxygen percentage and tissue perfusion. Guedes et al. (2007) found no change in $\mathrm{SpO}_{2}$ when working with multiple doses of morphine, and attributed the result to adequate oxygenation. In our study, after starting the supply of $100 \%$ oxygen, all animals displayed $\mathrm{SpO}_{2}$ values equal to or higher than $98 \%$, suggesting that tissue perfusion and oxygenation were properly maintained throughout the study. 


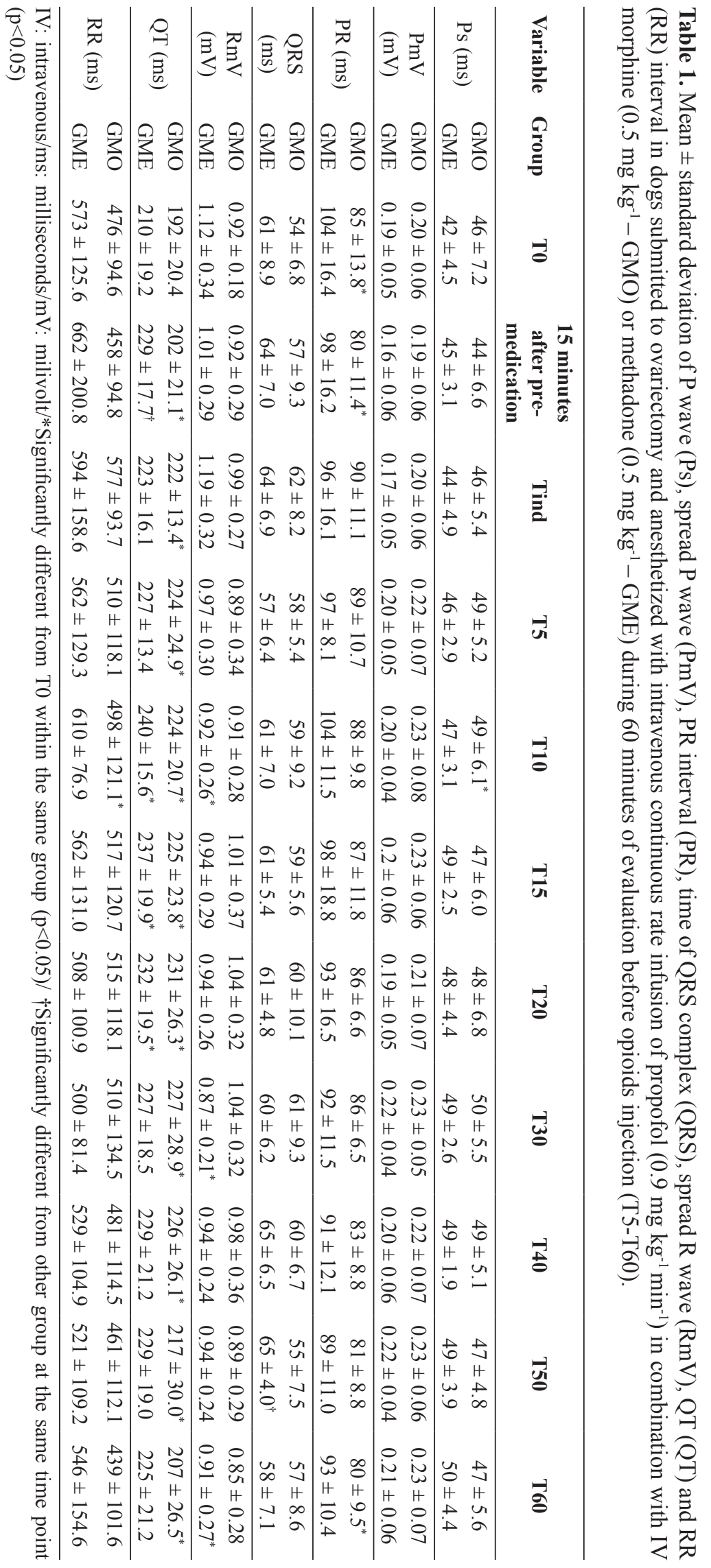




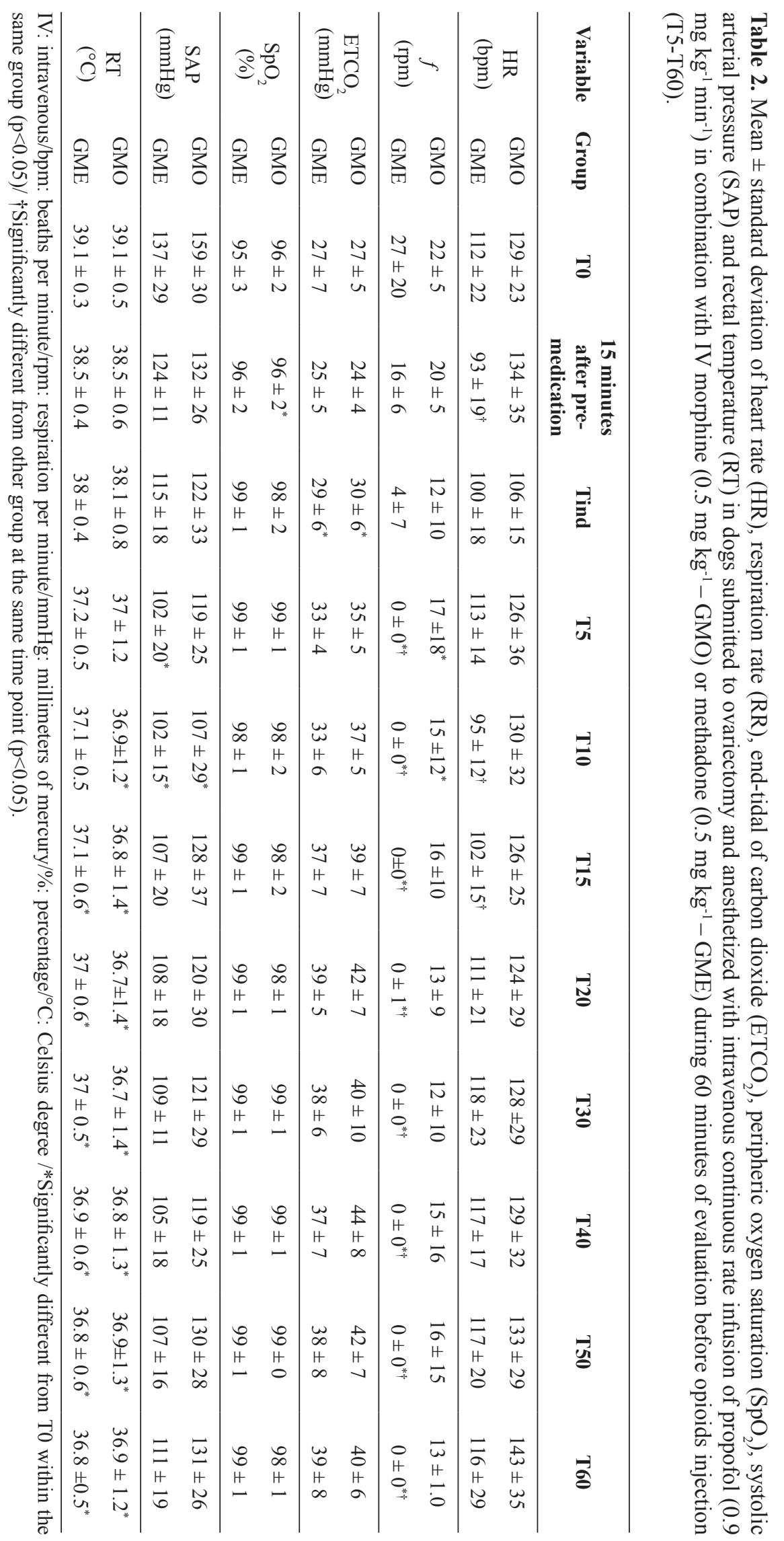


Regarding SBP, it was found that there was a reduction from baseline in both groups, and this reduction was significant at $\mathrm{T} 5$ and $\mathrm{T} 10$ in the GME group, and at T10 in the GMO group (Table 2). Propofol can reduce SBP by 15 to $30 \%$, and the dosedependent manner and the previous or subsequent administration of opioids may potentiate the hypotensive effect of the anesthetic (MAGELLAN; CHEIBUB, 1990). Also, in dogs anesthetized with isoflurane and treated with acepromazine, it was noted that this drug potentiated the hypotensive effects of inhalational anesthetics (MONTEIRO et al., 2007; GRASSO et al., 2015). Such observations corroborate the results of this study, indicating that the phenothiazine associated with the opioids in question may have enhanced the cardiovascular depressant effects of propofol.

Reduction in the mean arterial blood pressure was observed by Ferro et al. (2005) and Cortopassi et al. (2000), suggesting that depression was probably caused by propofol acting on vasomotor centers located in the brain stem, resulting in the combination of a reduced cardiac output and systemic vascular resistance, and possibly by the combination with other drugs (acepromazine in this case). Changes in blood pressure were not observed by Pereira et al. (2013), by implementing doses of $0.3 \mathrm{mg} \mathrm{kg}^{-1}$ of methadone, intramuscularly and intravenously in dogs. This resulted from the low dose used, and the minimal effects of opioids and the inhaled anesthetic agent on blood pressure, because these substances can reduce blood pressure as their concentrations or doses increase.

Regarding RT, there was a reduction in this parameter in both groups, which was significant from T10 onwards in GMO and from T15 onwards in GME (Table 2). This result could have been caused by the effect of acepromazine and the opioid promoting changes in the thermoregulatory mechanism (HALL et al., 2001; MONTEIRO et al., 2009). It is known that phenothiazine tranquilizers promote their effects by blocking an important range of neurotransmitters such as serotonin and dopamine in the CNS, as well as depressing the reticular system (FANTONI; CORTOPASSI, 2002). The blocking of dopamine receptors in the chemoreceptor trigger zone of the spinal cord depletes catecholamines in the thermoregulatory center of the hypothalamus leading to a loss of temperature control (LEMKE, 2007). Corroborating, Guedes et al. (2007) and Monteiro et al. (2008) reported a reduction in body temperature in dogs after administration of morphine and methadone; however, they attributed this to dyspnea, which was not observed in this study.

With regard to analgesia, there was no significant difference in VAS and the numeric scale in the assessment over time, or between groups (Table $3)$. Only one GMO group animal required rescue analgesia (VAS $=7$ ). In both groups the mean score was 3 , which corresponds to full analgesia according to the proposed scale.

Monteiro et al. (2016) analyzed the antinociceptive effects of methadone or morphine (0.5 mg kg-1 intramuscularly) associated with acepromazine in dogs by means of changes in the minimum alveolar concentration of isoflurane, and noted that the former opioid caused a reduction in this variable that was $50 \%$ higher than morphine, showing better analgesic effects of methadone when employing that method. No clinical studies comparing the analgesic effects of morphine and methadone were found in the literature, however, it is known that the relative potencies of these drugs are the same (HALL et al., 2001). Thus, respecting the pharmacokinetic differences, it is expected that by using the same route and dosage, the analgesic effects, especially for mild to moderate pain, should also be similar. It is worth highlighting that the methodology used to quantify pain followed subjective scales, and, therefore, there may have been variation between animals and evaluators. 
Table 3. Mean \pm standard deviation of the visual analogic scale (VAS) and analgesia score in dogs submitted to ovariectomy and anesthetized with intravenous continuous rate infusion of propofol $1\left(0.9 \mathrm{mg} \mathrm{kg}^{-1} \mathrm{~min}^{-1}\right)$ in combination with IV morphine ( $\left.0.5 \mathrm{mg} \mathrm{kg}^{-1}-\mathrm{GMO}\right)$ or methadone (0.5 $\left.\mathrm{mg} \mathrm{kg}^{-1}-\mathrm{GME}\right)$ during 360 minutes in pos-operatory (T120-T360).

\begin{tabular}{ccccccc}
\hline Variable & Grup & T120 & T180 & T240 & T300 & T360 \\
\hline VAS & GMO & $0 \pm 0$ & $0 \pm 0.3$ & $0 \pm 0.5$ & $1 \pm 2.5$ & $1 \pm 2.5$ \\
& GME & $0 \pm 0$ & $0 \pm 0$ & $0 \pm 0$ & $0 \pm 0$ & $0 \pm 0$ \\
Analgesia & GMO & $3 \pm 0$ & $3 \pm 0$ & $3 \pm 0$ & $3 \pm 1$ & $3 \pm 1$ \\
Score* & GME & $3 \pm 0$ & $3 \pm 0$ & $3 \pm 0$ & $3 \pm 0$ & $3 \pm 0$ \\
\hline
\end{tabular}

IV: intravenous/* Adapted from Firth and Haldane (1999).

\section{Conclusions}

Based on the results obtained, it can be concluded that methadone and morphine produce similar cardiovascular effects when injected IV, intraoperatively, in combination with intravenous continuous rate infusion of propofol. However, while using this protocol, continuous monitoring of the respiratory system is required, as there is the possibility of severe respiratory depression, especially with the use of methadone. Moreover, both drugs were effective in controlling postoperative pain following ovariohysterectomy for at least $6 \mathrm{hr}$.

\section{Acknowledgements}

We would like to thank the Fundação de Amparo a Pesquisa do Estado de São Paulo (FAPESP n. 08/ 00835-7).

\section{References}

CARDOSO, C. G.; MARQUES, D. R.; SILVA, T. H. da; MATTOS-JUNIOR, E. de. Cardiorespiratory, sedative and antinociceptive effects of dexmedetomidine alone or in combination with methadone, morphine or tramadol in dogs. Veterinary Anaesthesia and Analgesia, Oxford, v. 41, n. 6, p. 636-643, 2014.

CARROLL, G. L. Pré-medicações. In: . Anestesia e analgesia de pequenos animais. Barueri: Manole, 2008. cap. 5, p. 78-92.

CONCEIÇÃO, E. D. V. Infusão contínua de propofol associado ao fentanil ou sufentanil em cadelas submetidas à ovariossalpingo-histerectomia. 2006. Tese
(Doutorado em Cirurgia Veterinária) - Faculdade de Ciências Agrárias e Veterinárias, Universidade Estadual Paulista, Jaboticabal.

CORTOPASSI, S. R. G.; HOLZCHUH, M. P.; FANTONI, D. T. Anestesia geral com propofol em cães pré-tratados com acepromazina e alfentanil. Ciência Rural, Santa Maria, v. 30, n. 4, p. 635-644, 2000.

FANTONI, D. T.; CORTOPASSI, S. R. G. Medicação pré-anestésica. In: . Anestesia em cães e gatos. São Paulo: Roca, 2002. cap. 13, p. 150-158.

FERRO, P. C.; NUNES, N.; PAULA, D. P. de; NISHIMORI, C. T.; CONCEIÇÃO, E. D. V.; GUERRERO, P. N. H.; ARRUDA, L. M. Variáveis fisiológicas em cães submetidos à infusão contínua de diferentes doses de propofol. Ciência Rural, Santa Maria, v. 35, n. 5, p. 1103-1108, 2005.

FIRTH, A. M.; HALDANE, S. L. Development of a scale to evaluate postoperative pain in dogs. Journal of the American Veterinary Medical Association, New York, v. 214, n. 5, p. 651-659, 1999.

GOODWIN, J. K. Eletrocardiografia. In: TILLEY, L. P.; GOODWIN, J. K. Manual de cardiologia para cães e gatos. 3. ed. São Paulo: Roca, 2002. cap. 3, p. 39-65.

GRASSO, S. C.; KO, J. C.; WEIL, A. B.; PARANJAPE, V.; CONSTABLE, P. D. Hemodynamic influence of acepromazine or dexmedetomidine premedication in isoflurane-anesthetized dogs. Journal of the American Veterinary Medical Association, New York, v. 246, n. 7, p. 754-764, 2015.

GUEDES, A. G. P.; PAPICH, M. G.; RUDE, E. P.; RIDER, M. A. Pharmacokinetics and physiological effects of two intravenous infusion rates of morphine in conscious dogs. Journal of Veterinary Pharmacology and Therapeutics, Oxford, v. 30, n. 3, p. 224-233, 2007.

GUEDES, A. G. P.; RUDÉ, E. P.; RIDER, M. A. Evaluation of histamine release during constant rate 
infusion of morphine in dogs. Veterinary Anaesthesia and Analgesia, Oxford, v. 33, n. 1, p. 28-35, 2006.

HALL, L. W.; CLARKE, K. W.; TRIM, C. M. Principles of sedation, analgesia and premedication. In:

Veterinary Anaesthesia. $10^{\text {th }}$ ed. London: W. B. Saunders, 2001. cap. 4, p. 75-112.

INGVAST-LARSSON， C.; HOLGERSSON， A.; BONDESSON, U.; LAGERSTEDT, A. S.; OLSSON, K. Clinical pharmacology of methadone in dogs. Veterinary Anaesthesia and Analgesia, Oxford, v. 37, n. 1, p. 48-56, 2010.

JAFFE, J. H.; MARTIN, W. R. Analgésicos opioides e antagonistas. In: GILMAN, A. G.; RALL, T. W.; NIES, A. S.; TAYLOR, P. Goodman \& Gilman - as bases farmacológicas da terapêutica. 8. ed. Rio de Janeiro: Guanabara Koogan, 1991. p. 320-343.

LAMONT, L. A.; MATHEWS, K. A. Opioids, nonsteroidal anti-inflammatories, and analgesic adjuvants. In: TRANQUILI, W. J.; THURMON, J. C.; GRIMM, K. A. Lumb \& Jones' veterinary anesthesia and analgesia. $4^{\text {th }}$ ed. Iowa: Blackwell Publishing, 2007. cap. 10, p. 241-272.

LEMKE, K. A. Anticholinergics and sedatives. In: TRANQUILLI, W. J.; THURMON, J. C.; GRIMM, K. A. Lumb \& Jones' veterinary anesthesia and analgesia. $4^{\text {th }}$ ed. Iowa: Blackwell Publishing, 2007. cap. 9, p. 203239.

LERCHE, P.; MUIR, W. A. Analgesia. In: CARROLL, G. L. Anestesia e analgesia de pequenos animais. Barueri: Manole, 2008. cap. 9, p. 143-165.

MAGELLA, H. A.; CHEIBUB, Z. B. Propofol: revisão bibliográfica. Revista Brasileira de Anestesiologia, Rio de Janeiro, v. 40, n. 4, p. 284-294, 1990.

MAIANTE, A. A.; TEIXEIRA NETO, F. J.; BEIER, S. L.; CORRENTE, J. E.; PEDROSO, C. E. B. P. Comparison of the cardio-respiratory effects of methadone and morphine in conscious dogs. Journal of Veterinary Pharmacology and Therapeutics, Oxford, v. 32, n. 4, p. 317-328, 2008.

MATTU, A.; BRADY, W. J.; PERRON, A. D. Electrocardiographic manifestations of hypothermia. American Journal of Emergency Medicine, Philadelphia, v. 20, n. 4, p. 314-326, 2002.

MURISON, P. J. Effect of propofol at two injection rates or thiopentone on post-intubation apnoea in the dog. Journal of Small Animal Practice, v. 42, n. 2, p. 71-74, 2001.

MONTEIRO, E. R.; COELHO, K.; BRESSAN, T. F.; SIMÕES, C. R.; MONTEIRO, B. S. Effects of acepromazine-morphine and acepromazine-methadone premedication on the minimum alveolar concentration of isoflurane in dogs. Veterinary Anaesthesia and Analgesia, Oxford, v. 43, n. 1, p. 27-34, 2016.

MONTEIRO, E. R.; FIGUEROA, C. D.; CHOMA, J. C.; CAMPAGNOL, D.; BETTINI, C. M. Effects of methadone, alone or in combination with acepromazine or xylazine, on sedation and physiologic values in dogs. Veterinary Anaesthesia and Analgesia, Oxford, v. 35, n. 6, p. 519-527, 2008.

MONTEIRO, E. R.; RODRIGUES, A.; ASSIS, H. M. Q.; CAMPAGNOL, D.; QUITZAN, J. G. Comparative study on the sedative effects of morphine, methadone, burtofanol or tramadol, in combination with acepromazine, in dogs. Veterinary Anaesthesia and Analgesia, Oxford, v. 36, n. 1, p. 25-33, 2009.

MONTEIRO, E. R.; TEIXEIRA NETO, F. J.; CASTRO, V. B.; CAMPAGNOL, D. Effects of acepromazine on the cardiovascular actions of dopamine in anesthetized dogs. Veterinary Anaesthesia and Analgesia, Oxford, v. 34, n. 5, p. 312-321, 2007.

MURISON, P. J. Effect of propofol at two injection rates or thiopentone on post-intubation apnoea in the dog. Journal of Small Animal Practice, Oxford, v. 42, n. 2, p. 71-74, 2001.

NISHIMORI, C. T. D. Índice biespectral, variáveis intracranianas e cardiovasculares em cães anestesiados com diferentes doses de infusão de propofol, associadas ou não ao óxido nitroso. 2006. Tese (Doutorado em Cirurgia Veterinária) - Faculdade de Ciências Agrárias e Veterinárias, Universidade Estadual Paulista, Jaboticabal.

NOLAN, A. M.; REID, J. Comparison of the postoperative analgesic and sedative effects of carprofen and papaveretum in the dog. The Veterinary Record, London, v. 133, n. 10, p. 240-242, 1993.

NUNES, N.; REZENDE, M. L.; SANTOS, P. S.; MARTINS, S.E. Effects of levomepromazine and different desflurane concentrations upon electrocardiographic variables in dogs. Veterinary Anaesthesia and Analgesia, Oxford, v. 31, n. 1, p. 73-77, 2004.

PEREIRA, D. A.; MARQUES, J. A.; BORGES, P. A.; BATISTA, P. A. C. S.; OLIVEIRA, C. A.; NUNES, N.; LOPES, P. C. F. Efeitos cardiorrespiratórios da metadona pelas vias intramuscular e intravenosa, em cadelas submetidas à ovariossalpingo-histerectomia. Arquivo Brasileiro de Medicina Veterinária e Zootecnia, Belo Horizonte, v. 65, n. 4, p. 967-974, 2013.

PIRES, J. S.; CAMPELLO, R. A. V.; FARIA, R. X.; GUEDES, A. G. P. Anestesia por infusão contínua de propofol em cães pré-medicados com acepromazina e 
fentanil. Ciência Rural, Santa Maria, v. 30, n. 5, p 829$834,2000$.

SANTOS, P. S. P.; NUNES, N.; SOUZA, N. A. P.; REZENDE, M. L.; NISHIMORI, C. T.; PAULA, D. P. de; GUERREIRO, P. N. H. Efeitos eletrocardiográficos do butorfanol em cães anestesiados pelo desfluorano. Ciência Rural, Santa Maria, v. 34, n. 4, p. 1105-1111, 2004.

SANTOS, P. S. P.; NUNES, N.; VICENTI, F. A. M. Estudo eletrocardiográfico, em cães tratados com concentrações decrescentes de desflurano. Ars Veterinária, Jaboticabal, v. 16, n. 1, p. 16-21, 2000.

SANTOS, P. S. P.; NUNES, N.; VICENTI, F. A. M.; MARTINS, S. E. C.; REZENDE, M. L. Eletrocardiografia de cães submetidos a diferentes concentrações de desflurano, pré-tratados ou não com a associação de fentanil/droperidol. Ciência Rural, Santa Maria, v. 31, n. 5, p. 805-811, 2001.

STANLEY, T. H.; LIU, W. S.; WEBSTER, L. R.; JOHANSEN, R. K. Haemodynamic effects of intravenous methadone anaesthesia in dogs. Canadian Anaesthetists' Society Journal, Toronto, v. 27, n. 1, p. 52-57, 1980.
STEPHENSON, R. B. O eletrocardiograma. In: CUNNINGHAM, J. G. Tratado de fisiologia veterinária. Rio de Janeiro: Guanabara Koogan, 1993. cap. 19, p. 113-122.

THURMON, J. C.; TRANQUILLI, W. J.; BENSON, G. J. Preanesthetics and anesthetic adjuncts. In:

Lumb and Jones' Veterinary anaesthesia and analgesia. $3^{\text {th }}$ ed. Baltimore: Williams and Wilkins, 1996. p. 40-60.

TILLEY, L. P. Essentials of canine and feline electrocardiographic: interpretation and treatment. $3^{\text {th }}$ ed. Philadelphia: Lea \& Feabinger, 1992. 470 p.

TILLEY, L. P.; BURTNICK, N. L. ECG electrocardiography for the small animal practitioner. Wyoming: Teton NewMedia, 1999. 105 p.

VALADÃO, C. A. A.; DUQUE, J. C.; FARIAS, A. Administração epidural de opióides em cães. Ciência Rural, Santa Maria, v. 32, n. 2, p. 347-355, 2002

WAGNER, A. E. Opioids. In: GAYNOR, J. S.; MUIR, W. W. Handbook veterinary pain management. St Louis: Mosby, 2002. p. 164-183 